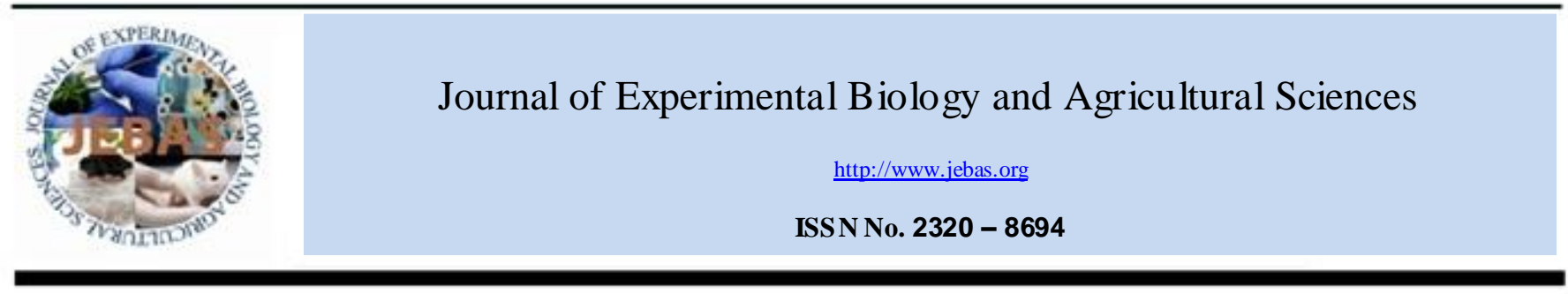

\title{
SELECTION OF PHENOTYPIC INTERESTS FOR THE CULTIVATION OF THE PLANT Cleome gynandra L. IN THE VEGETABLE GARDENS IN BURKINA FASO
}

\section{Zakaria KIEBRE*, Pauline BATIONO/KANDO, Nerbéwendé SAW ADOGO, Mahamadou SAWADOGO and Jean-Didier ZONGO}

Equipe de recherche en Génétique et Amélioration des plantes Laboratoire Biosciences, Unité de Formation et de Recherche en S ciences de la Vie et de la Terre, Université de Ouagadougou; 03 BP 7021 Ouagadougou 03; Burkina Faso.

Received - March 24, 2015; Revision - April 10, 2015; Accepted - June 10, 2015

Available Online - June 19, 2015

DOI: http://dx.doi.org/10.18006/2015.3(3).288.297

\section{KEYWORDS \\ Cleome gynandra \\ Selection \\ Agromorphological \\ characterization \\ Burkina Faso}

\begin{abstract}
ABSTRAC T
Present study was aimed to understand the scientific basis of the farmer's nomenclature of the local varieties of Cleome gynandra L. and to identify the characters of interests that can be used for the varietal improvement of the species. A survey was carried out in five cities of Burkina Faso with 56 producers of C. gynandra with the help of semi-structured interviews to identify the preferential characters. Furthermore thirty accessions were collected and evaluated in July 2014 at Gampela according to randomized complete block design with seventeen variables. The study revealed that in the denomination of local varieties, the farmers use agromorphological characters such as the color of the stem, leaves and the vegetative cycle of the plant. It was also revealed that the selection of plant in the vegetable garden s is preferred for the green color of the stem, leaves, long vegetative cycle, height of the plant, dimensions of the leaves and the number of primary branches. These were the selective interests for the farmers identified during the survey. The study also revealed that the process of selection is more advanced in Ouagadougo $u$, where the demand is very high and where the consumers are more as compared to the other localities where the choice of the plant has just began for consumption. The results of this study have permitted to undertake the varietal improvement of the species according to the needs of the producers whose majority have a particular preference for the green ecotypes with long cycle.
\end{abstract}

* Corresponding author

E-mail: kiebzak@yahoo.fr (Zakaria KIEBRE)

Peer review under responsibility of Journal of Experimental Biology and Agricultural Sciences.

Production and Hosting by Horizon Publisher (www.my-

vision.webs.com/horizon.html).

All rights reserved.
All the article published by Journal of Experimental Biology and Agricultural Sciences is licensed under a Creative Commons Attribution-NonCommercial 4.0 International License Based on a work at www.jebas.org.

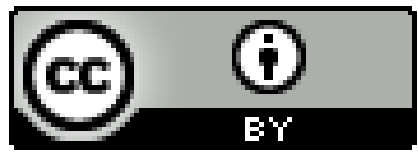




\section{Introduction}

Cleome gynandra L. is an annual plant of the family Capparaceae (Short, 2011). It is commonly known as spider flower, spider plant, cats' whiskers or African cabblage. Plant originated in tropical Africa and South-East Asia (Chweya \& Mnzava, 1997) it used as leafy vegetable in these areas (DAFF, 2010). Leaves of the plant are rich in vitamin $A$ and $C, \beta$ carotene, iron, calcium, magnesium, protein, phosphorus (Chweya \& Mnzava, 1997; Soro et al., 2012; Agbo et al., 2014) and it plays an important role in the overcoming nutritional deficiencies. This vegetable stimulates the restoration of blood after delivery by increasing the number of red blood cells and the corpuscular hemoglobin concentration. In fact, it stimulates the synthesis of iron biomarkers such as transferrin and ferritin (Bosire, 2014). In Burkina Faso, C. gynandra also used as a food of famine, floods and dryness (Millogo- Rasolodimby, 2001) becomes more popular leafy vegetable because of its national interest.

Traditionally it harvested directly from the nature and used as a dietary supplement, nowadays, this vegetable is in domestication in vegetable gardens. Domestication is the process which involved genetic transformation of naturally existing form into the human required form. Thus, C. gynandra gradually undergoes in the selection for vegetable gardens according to the preferential criteria of producers and consumers. The knowledge of these criteria is very important for varietal improvement that must take into account the needs and preferences of the producers and the consumers. Thus present study has been conducted on the general framework of the varietal improvement of $C$. gynandra aims (i) to understand the scientific basic nomenclatures of local varieties adopted by farmers, (ii) to identify the characters morphological interest of this plant, which can be used in plant breeding and to estimate their heritability and (iii) and to study the agromorphological diversity.

\section{Material and Methods}

\subsection{Genetic material}

Thirty (30) accessions of $C$. gynandra were randomly collected from the vegetable gardens, of five different localities of Burkina Faso i.e. Ouagadougou, the capital $\left(1^{\circ} 31^{\prime} 05^{\prime \prime} \mathrm{W} 12^{\circ}\right.$ $\left.21^{\prime} 58^{\prime \prime} \mathrm{N}\right)$, Bobo Dioulasso (4० $\left.17^{\prime} 00^{\prime \prime} \mathrm{W}, 11^{\circ} 11^{\prime} 00^{\prime \prime} \mathrm{N}\right)$, Hounde $\left(3^{\circ} 31^{\prime} 0 \mathrm{~W}, 11^{\circ} 300 \mathrm{~N}\right)$, Boromo $\left(2^{\circ} 55^{\prime} 53^{\prime \prime} \mathrm{W}, 11^{\circ} 44^{\prime}\right.$ $\left.55^{\prime \prime} \mathrm{N}\right)$ and Toma $\left(4^{\circ} 25^{\prime} \mathrm{W}, 12^{\circ} 38^{\prime} \mathrm{N}\right)$. During the collection, surveys were conducted from 56 producers through semistructured questionnaire based interviews to know the preferential characters. The questionnaire designed to extract the information like number of locally cultivated varieties, names of local varieties cultivated by farmers, the morphological characters of interest for producers and consumers, the seeds obtainment modes, the plant cultivation period, the aim of the cultivation (consummation or selling), the accessions first cultivation date, etc.

\subsection{Study site}

The agromorphological evaluation was conducted at the research station of Gampela, agronomic research center of the Institute of Rural Development (IDR). The neighborhood is located in North-Sudan zone $\left(1^{\circ} 21^{\prime} \mathrm{W}\right.$ and $\left.12^{\circ} 24^{\prime} \mathrm{N}\right)$, with an annual rainfall ranging from 600 to $900 \mathrm{~mm}$ (Thiombiano \& Kampmann, 2010). The maximal annual temperature varies between 35 to $40^{\circ} \mathrm{C}$ and minimal temperature varies between 18 to $19^{\circ} \mathrm{C}$.

\subsection{Experimental design}

The study was conducted in randomized complete block design (RCBD). Each block was separated by one meter distance. In each block every accession was represented by a row of 5 meters on which 11 hills were sown. The spaces between the rows and the plants were $0.5 \mathrm{~m}$. Because of the low rate of the seeds germination, ten seed per hill were sown. A thinning to one plant per hill was then done 10 days after sowing. Before starting trial, the land was plowed, amended with organic matter and leveled. An application of NPK (15-15-15) was carried out at the rate of $200 \mathrm{~kg} / \mathrm{ha}$.

\subsection{Characters measured and variables analyzed}

Seventeen (17) variables including six (6) qualitative and eleven (11) quantitative traits were analyzed. Except the number of days to $50 \%$ flowering and the number of days to plants emergence measured on the entire row, the other quantitative variables were measured on 4 plants by row 45 days after sowing. These studied traits are the plant height (measured from the ground to the last leaf of the main stem); stem diameter; number of primary branches; the length of leaflet (measured from the top from the pulvinus of the central leaflet); the width of leaflet (measured at the middle portion of the central leaflet); the length of petiole (measured to the sheath from the pulvinus) and the biomass of leaves. The fruit length and the fruit width were also measured on the three first fruits of four plants per row. The stem color, leaf color, flower pieces color, the plant pubescence, the plant type (erect, semierect), the fruit shape and the flowers abundance were also observed throughout the plant cycle.

\subsection{Statistical analysis}

Analysis of variance (ANOVA) was performed using the Gen Stat v4.10.3 software (VSN International, 2011) on the quantitative variables to determine those that discriminate the accessions. It also aimed to know, after separation of the means by Newman-Keuls test of separation of means at $5 \%$, if there are significant differences between the accessions of the 5 cities on the one hand, and bet ween the different modes of seeds obtainment by the producers on other hand. For each of discriminating characters, the broad sense herit ability $\left(\mathrm{H}^{2}\right)$ was calculated using the genotypic variances (VG) and phenotypic 
variances (VP): $\mathrm{H}^{2}(\%)=(\mathrm{VG} / \mathrm{VP}) * 100($ Johnson et al., 1955). The software XLSTAT 2013.2.03 has served to multivariate analysis. A principal component analysis was performed and the coordinates of individuals from this analysis were used to accessions regrouping by hierarchical cluster analysis. The clusters obtained from this analysis were characterized by factorial discriminating analysis.

\section{Results}

\subsection{Botanical characterization of available varieties}

Result of the study revealed that the gardeners of Oua gado ugo u produced C. gynandra in any season of the year they produced it mainly for the selling. Thus, in a year this plant undergoes several cultivation cycles. Contrary, in the other localities, it produced only in rainy season for family consummation. Therefore suffers less cultivation cycles per year compared to accessions of Ouagadougou.

Producers use three modes to obtain seeds (Table 1). The seeds have undergone several cultivation cycles, whose the first cultivation date is over 5 years. These are obtained by selection from population. The seeds obtained by purchase/donation for the first cultivation date is unknown. The seeds having undergone only 1-2 cultivation cycles for the first cultivation date is one year. These have recently taken from the natural ecotypes. In the capital, Ouagadougou, producers primarily use seeds from selection and purchase/donation respectively 53 and $40 \%$ of producers, while in the other localities, it's recently cultivated seeds that are encountered in gardens (40 to $75 \%$ of the producers).

For the nomenclature of the local varieties of $C$. gynandra, producers mainly used stem color and plant cycle. With reference to the stem color, two morphotypes were reported in the studied localities. Among these two, first morphotype is with green stem called in moore "keneb Pelga" which means "white C. gynandra" and the second morphotype with violet stem called "keneb miougou" in moore which means "red $C$. gynandra" However, $3.33 \%$ of the Ouagado ugo u producers distinguish two types of green morphotypes viz local and improved (or introduced) type. Here, improved or introduced type of C. gynandra is called in moore "Tampouy kenebdo" or "Baskuy kenebdo" with reference to the district where the seeds were purchased from the store. Improved or introduced type also called "Nasaa $n$ kenebdo" which means "European $C$. gynandra" indicating that it would be an improved variety or introduced variety. This improved variety was characterized by long plant height, high plant pubescence and a long cycle.

The majority of gardeners $(83.33 \%)$ prefer the green variety with a long cycle for the consumer's needs (organoleptic quality, great biomass) while only $16.67 \%$ of producers who are indifferent to stem color. With reference to the plant cycle, Ouagado ugo u's producers distinguish two local varieties: a variety called "keneb raaga" which means "Male $C$. gynandra " due to its early flowering, abundant production of flowers and a small plant height while the second variety was known by moore "keneb gnan-ga" which means " female $C$. gynandra" due to its late flowering, long plant height and few flowers. Although, in moore, "keneb raaga" (male $C$. gynandra) is most often used to refer $C$. viscosa, some gardeners $(53.33 \%)$ use it to refer to varieties of Cleome gynandra L. with short cycle. All Ouagado ugo u's producers prefer the variety with a long vegetative cycle while those of the other cities do not have preferences.

\subsection{Agromorphological evaluation}

\subsubsection{Phenotypic variability using qualitative characters}

Agromorphological evaluations have been suggested two types of morphotypes on the basis of stem and leaf color (Figure 1). A morphotype with green stem and cleared green leaves (Figure 1a) mostly met in accessions from Ouagadougou vegetable gardens $(68.75 \%)$ and morphotype with very violet stem (Figure 1b) or slightly violet stem (Figure 1c) having dark-green leaves, mostly met in accessions from the other localities (50-75\%).

Table 1 Distribution of surveyed farmers for cultivation period and the seeds obtainment modes by city.

\begin{tabular}{|lccccc|}
\hline Cities & $\begin{array}{c}\text { Sea sons of Production }(\%) \\
\text { Both Rainy and } \\
\text { dry season }\end{array}$ & $\begin{array}{c}\text { Only in Rainy } \\
\text { Sea son }\end{array}$ & Selection & $\begin{array}{c}\text { Mode of Seed Collection }(\%) \\
\text { Purchase / } \\
\text { donation }\end{array}$ & $\begin{array}{c}\text { Recently collected } \\
\text { from nat ural ecotypes }\end{array}$ \\
\hline Ouagado ugou & 60 & 40 & 53 & 40 & 6.66 \\
\hline Bobo & 50 & 50 & 25 & 25 & 50 \\
\hline Houndé & 0 & 100 & 13 & 12 & 75 \\
\hline Toma & 0 & 100 & 30 & 30 & 45 \\
\hline Boromo & 33.33 & 66.67 & & & 40 \\
\hline
\end{tabular}




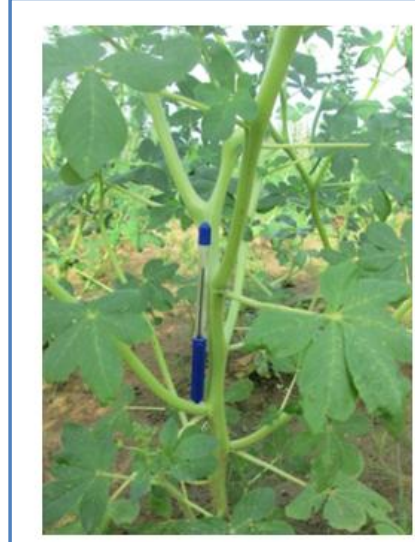

a: Green morphotype

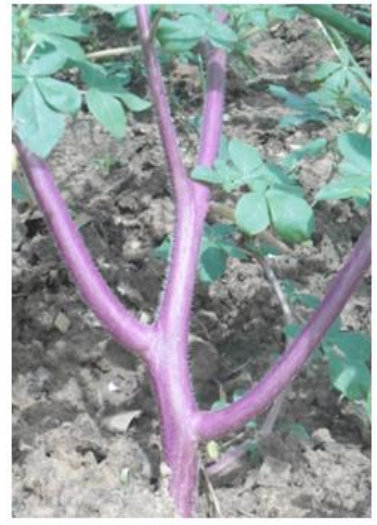

b: Violet morphotype

Figure 1 Variation of the stem color of C. gynandra.

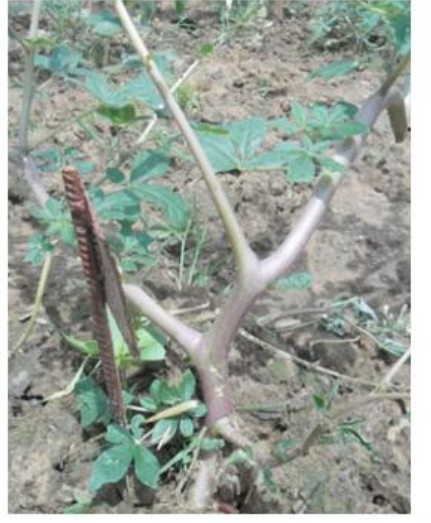

c: Slightly violet morphotype

Table 2 Analysis of the variation in qualitative characters of the collection of $C$. gynandra according to the collection sites (\%).

\begin{tabular}{|c|c|c|c|c|c|c|}
\hline \multirow[t]{2}{*}{ Variables } & \multirow[t]{2}{*}{ Modality } & \multicolumn{5}{|c|}{ Cities } \\
\hline & & Ouaga & Bobo & Hounde & Toma & Boromo \\
\hline \multirow[t]{3}{*}{ Stem color } & green: & 68.75 & 25 & 0 & 50 & 25 \\
\hline & violet: & 25 & 50 & 75 & 50 & 75 \\
\hline & variable: & 6.25 & 25 & 25 & 0 & 0 \\
\hline \multirow[t]{3}{*}{ Leaf color } & cleared-green: & 68.75 & 25 & 0 & 50 & 25 \\
\hline & dark-green: & 25 & 50 & 75 & 50 & 75 \\
\hline & variable: & 6.25 & 25 & 25 & 0 & 0 \\
\hline \multirow[t]{3}{*}{ Plant type } & erect & 62.5 & 0 & 0 & 66.67 & 66.67 \\
\hline & semi-erect & 31.25 & 75 & 75 & 33.33 & 33.33 \\
\hline & variable & 6.25 & 25 & 25 & 0 & 0 \\
\hline \multirow[t]{3}{*}{ Flowers abundance } & few a bun dant: & 81.25 & 0 & 0 & 33.33 & 33.33 \\
\hline & very abundant: & 12.5 & 100 & 100 & 66.67 & 66.67 \\
\hline & variable: & 6.25 & 0 & 0 & 0 & 0 \\
\hline \multirow[t]{3}{*}{ Fruits Shape } & big an d rough: & 75 & 12 & 13 & 15 & 33.33 \\
\hline & thin and smooth: & 48 & 75 & 75 & 75 & 66.67 \\
\hline & variable: & 6.25 & 13 & 12 & 10 & 0 \\
\hline \multirow[t]{3}{*}{ Plant pubescence } & great: & 25 & 25 & 33.33 & 0 & 25 \\
\hline & weak: & 68.75 & 75 & 66.67 & 100 & 50 \\
\hline & variable & 6.25 & 0 & 0 & 0 & 25 \\
\hline
\end{tabular}

Ouaga: Ouaga dougou, Bo bo: Bobo Dioulasso

The table 2 and 3 shows variation in the qualitative characters in the collection of $C$. gynandra respectively according to the collection sites and the seeds obtainment modes. Results of these tables revealed that the accessions with green stems, cleared-green leaves, few flowers, big rough fruit (Figure 2a) and erect type are mostly encountered in those from Ouagadougou, obtained by selection. On the contrary, accessions with violet stem, dark-green leaves, many flowers, thin and smooth fruits (Figure $2 b$ ), semi erect type are mostly encountered in those from the other localities, recently collected from natural populations. For the entire collection, the majority of accessions of all the cities show the plant present with variation in pubescence (Figure $3 a \& b$ ). Except floral pieces, all the characters studied were polymorphic and reported variability inside accessions for each of the variables analyzed.

\subsubsection{Phenotypic variability using quantitative characters}

Analysis of variance (Table 4) revealed highly significant differences at $1 \%$ between the accessions for all the characters studied except the number of flowers pieces. All the coefficients of variation are low $(<30 \%)$ except for the leaves biomass which was reported higher than $30 \%$. At 45 days after sowing, the plants have in an average height and biomass $61.60 \mathrm{~cm}$ and $71.96 \mathrm{~g}$ respectively. 


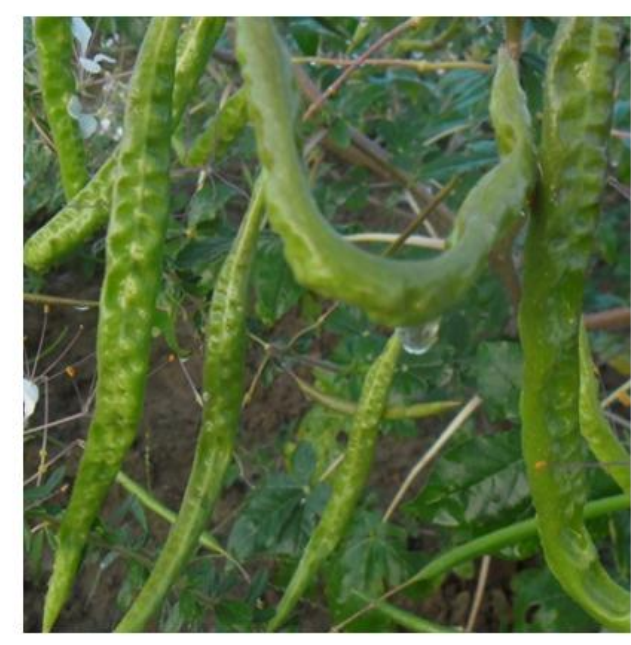

a: Big an d rough fruits

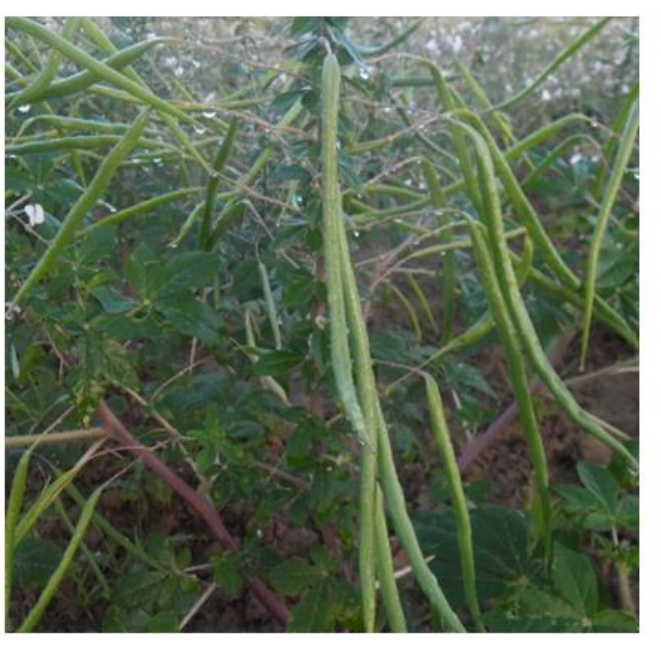

b: Thin and smooth fruits

Figure 2 variation of fruits shape of C. gynandra L.

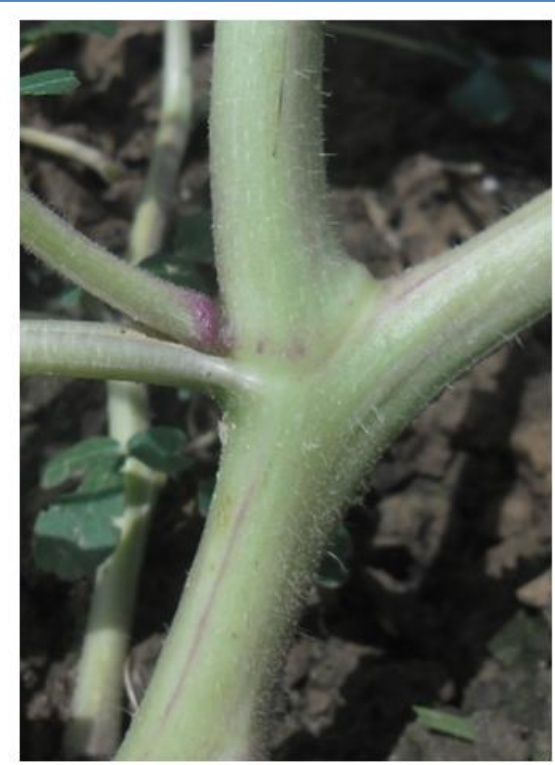

a: Weak pubescence

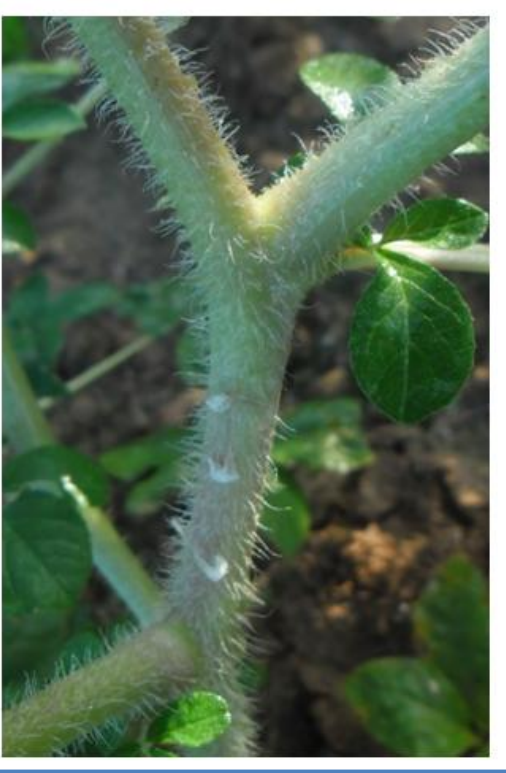

b: Great pubescence

Figure 3 variation of pubescence of $C$. gynandra $\mathrm{L}$.

Table 3 Variation in some qualitative characters in the collection of $C$. gynandra according to the seeds obtainment modes.

\begin{tabular}{|lccc|}
\hline Variables & Selection & $\begin{array}{c}\text { Purchase/ } \\
\text { donation }\end{array}$ & $\begin{array}{c}\text { Recently taken from the nat ural } \\
\text { ecotypes }\end{array}$ \\
\hline Green stem, cleared-green leaves & 55.6 & 50 & 18.18 \\
Violet stem, dark-green leaves & 44.4 & 50 & 81.82 \\
\hline Big and rough fruits & 60 & 77.78 & 18.18 \\
Thin and smooth fruits & 40 & 22.22 & 81.82 \\
\hline Few abundant flowers & 60 & 77.78 & 18.18 \\
Very abundant flowers & 40 & 22.22 & 81.82 \\
\hline
\end{tabular}


The emergence of the plants varies from 4 to 7 days after sowing and heritability is higher for all the reported characters (>80\%). According to Johnson et al. (1955), the heritability $\left(\mathrm{H}^{2}\right)$ is higher when its value is greater than $50 \%$. Also, there are highly significant differences at $1 \%$ between the seeds obtainment modes for all the characters studied (Table 5). The accessions from the selection have higher performances of vegetative growth parameters than the others. The weakest performances were noted in accessions collected in the natural population. In addition, the geographical origins effects, highly significant at $1 \%$ (Table 6) were observed for all the characters. Those collected from Ouagadougou have higher performance than those collected in the other localities.

\subsubsection{Principal component analysis}

The first three components (Table 7) show $85.39 \%$ of the total variability. It revealed that the plant height, plant diameter, primary branches number, leaf dimensions, fruit length and the leaves biomass are associated with the first factor (F1) which explains $59.13 \%$ of the variability. The number of days of emergence and the fruit width are associated with the second factor (F2) which explains $18.03 \%$ of the diversity observed. The cycle of the plant is associated with the third factor (F3) and explains $8.23 \%$ of the variability.

\subsubsection{Agromorphological diversity structuring}

Agglomerative hierarchical clustering (Figure 4) based on the factor scores of the tree factors (F1, F2 and F3) revealed that the accessions form three distinctive clusters with $83.02 \%$ dissimilarity between clusters and $16.98 \%$ dissimilarity within cluster. Cluster 1 has the best agronomic performances. It mainly contains the accessions from Ouagadougou, obtained by selection. Cluster 2, formed by the accessions from diverse geographical origins including some from Ouagadougou, it contains mostly the accessions obtained by purchase / donation.

Table 4 Performances of accessions studied, ANOVA results and broad sense heritability of eleven characters.

\begin{tabular}{|lcccccc|}
\hline Variables & Min. & Max. & Means & CV\% & F & $H^{2}(\%)$ \\
\hline Plant height $(\mathrm{cm})$ & 36.67 & 87.40 & $61.60 \pm 12,47$ & 20.24 & $10.32^{* *}$ & 97.19 \\
\hline Stem diameter $(\mathrm{cm})$ & 1.10 & 2.02 & $1.56 \pm 0,41$ & 25.92 & $4.11^{* *}$ & 80.65 \\
\hline Primary branches number & 3.08 & 7.00 & $4.87 \pm 1,34$ & 27.51 & $6.14 * *$ & 84.36 \\
\hline Petiole length $(\mathrm{cm})$ & 4.71 & 11.16 & $8.67 \pm 2,17$ & 25.00 & $5.65 * *$ & 84.40 \\
\hline Leaflet length $(\mathrm{cm})$ & 4.56 & 9.49 & $7.06 \pm 1,33$ & 18.82 & $9.59 * *$ & 90.12 \\
\hline Leaflet width $(\mathrm{cm})$ & 1.97 & 3.83 & $3.02 \pm 0,51$ & 16.80 & $8.13 * *$ & 89.81 \\
\hline Fruit width $(\mathrm{cm})$ & 0.33 & 0.77 & $0.58 \pm 0,11$ & 19.27 & $10.56^{* *}$ & 91.11 \\
\hline Fruit length $(\mathrm{cm})$ & 7.88 & 13.74 & $11.00 \pm 1,72$ & 15.60 & $7.47 * *$ & 86.95 \\
\hline 50\%flowering & 21.33 & 24.00 & $23.32 \pm 0,68$ & 2.93 & $14.15^{* *}$ & 93.07 \\
\hline Leaves biomass $(\mathrm{g})$ & 17.00 & 130.73 & $71.96 \pm 46,91$ & 65.18 & $4.69 * *$ & 81.30 \\
\hline DPE & 4.00 & 7.00 & $5.00 \pm 0,57$ & 11.54 & $19.96^{* *}$ & 95.26 \\
\hline
\end{tabular}

DPE: number of days to plants emergence, Min.: Minimum, Max.: Maximum, CV\% $=$ coefficient of variation, F: $\mathrm{F}$ of Fisher $* *$ : significant at $1 \%, \mathrm{H}^{2}$ : Heritability, \pm : standard error

Table 5 Reproductive and vegetative growth parameters of accessions of Cleome gynandra L. according to the seeds obtainment modes.

\begin{tabular}{|c|c|c|c|}
\hline \multirow[b]{2}{*}{ Variables } & \multicolumn{3}{|c|}{ Seeds obtainment modes by the producers } \\
\hline & Selection & Purchase/ donation & Recently taken from the natural ecotypes \\
\hline Plant height $(\mathrm{cm})$ & $70.62 \mathrm{~A}$ & $59.32 \mathrm{~B}$ & $53.64 \mathrm{C}$ \\
\hline Stem diameter $(\mathrm{cm})$ & $1.74 \mathrm{~A}$ & $1.48 \mathrm{~B}$ & $1.43 \mathrm{~B}$ \\
\hline Primary branches number & $5.49 \mathrm{~A}$ & $5.00 \mathrm{~B}$ & $4.10 \mathrm{C}$ \\
\hline Petiole length $(\mathrm{cm})$ & $9.74 \mathrm{~A}$ & $8.24 \mathrm{~B}$ & $7.87 \mathrm{~B}$ \\
\hline Leaflet length $(\mathrm{cm})$ & $7.81 \mathrm{~A}$ & $6.99 \mathrm{~B}$ & $6.30 \mathrm{C}$ \\
\hline Leaflet width $(\mathrm{cm})$ & $3.29 \mathrm{~A}$ & $2.98 \mathrm{~B}$ & $2.76 \mathrm{C}$ \\
\hline Fruit width $(\mathrm{cm})$ & $0.62 \mathrm{~A}$ & $0.52 \mathrm{~B}$ & $0.58 \mathrm{~A}$ \\
\hline Fruit length $(\mathrm{cm})$ & $11.40 \mathrm{~A}$ & $10.85 \mathrm{AB}$ & $10.69 \mathrm{~B}$ \\
\hline $50 \%$ flowering & $23.63 \mathrm{~A}$ & $23.11 \mathrm{~B}$ & $23.17 \mathrm{~B}$ \\
\hline Leaves biomass (g) & $94.68 \mathrm{~A}$ & $67.97 \mathrm{~B}$ & $50.47 \mathrm{C}$ \\
\hline DPE & $4.61 \mathrm{~B}$ & $5.25 \mathrm{~A}$ & $5.16 \mathrm{~A}$ \\
\hline
\end{tabular}

DPE: number of days to plant emergence. 
Table 6 Reproductive and veget ative growth parameters of accessions of $C$. gynandra according to the collection sites.

\begin{tabular}{|lccccc|}
\hline Variables & \multicolumn{3}{c|}{ Geographical origin of the accessions } \\
& Ouaga & Bobo & Boromo & Hounde & Toma \\
\hline Plant height $(\mathrm{cm})$ & $66.72^{\mathrm{a}}$ & $54.46^{\mathrm{b}}$ & $58.17^{\mathrm{b}}$ & $37.93^{\mathrm{c}}$ & $57.77^{\mathrm{b}}$ \\
\hline Stem diameter $(\mathrm{cm})$ & $1.66^{\mathrm{a}}$ & $1.34^{\mathrm{c}}$ & $1.44^{\mathrm{bc}}$ & $1.16^{\mathrm{c}}$ & $1.61^{\mathrm{ab}}$ \\
\hline Primary branches number & $5.38^{\mathrm{a}}$ & $3.98^{\mathrm{bc}}$ & $4.67^{\mathrm{b}}$ & $3.2^{\mathrm{c}}$ & $4.37^{\mathrm{b}}$ \\
\hline Petiole length $(\mathrm{cm})$ & $9.07^{\mathrm{a}}$ & $7.51^{\mathrm{b}}$ & $9.31^{\mathrm{a}}$ & $4.90^{\mathrm{c}}$ & $8.95^{\mathrm{a}}$ \\
\hline Leaflet length $(\mathrm{cm})$ & $7.59^{\mathrm{a}}$ & $5.83^{\mathrm{c}}$ & $6.92^{\mathrm{b}}$ & $4.69^{\mathrm{d}}$ & $6.97^{\mathrm{b}}$ \\
\hline Leaflet width $(\mathrm{cm})$ & $3.21^{\mathrm{a}}$ & $2.60^{\mathrm{c}}$ & $2.93^{\mathrm{b}}$ & $2.07^{\mathrm{d}}$ & $3.04^{\mathrm{ab}}$ \\
\hline Fruit width $(\mathrm{cm})$ & $0.56^{\mathrm{b}}$ & $0.51^{\mathrm{c}}$ & $0.65^{\mathrm{a}}$ & $0.50^{\mathrm{c}}$ & $0.69^{\mathrm{a}}$ \\
\hline Fruit length $(\mathrm{cm})$ & $11.18^{\mathrm{a}}$ & $10.43^{\mathrm{b}}$ & $11.23^{\mathrm{a}}$ & $9.38^{\mathrm{b}}$ & $11.17^{\mathrm{a}}$ \\
\hline 50\%flowering & $23.43^{\mathrm{a}}$ & $23.25^{\mathrm{a}}$ & $23.44^{\mathrm{a}}$ & $21.87^{\mathrm{b}}$ & $23.33^{\mathrm{a}}$ \\
\hline Leaves biomass $(\mathrm{g})$ & $87.01^{\mathrm{a}}$ & $55.14^{\mathrm{b}}$ & $57.70^{\mathrm{b}}$ & $17.36^{\mathrm{b}}$ & $54.78^{\mathrm{b}}$ \\
\hline DPE & $5.07^{\mathrm{b}}$ & $5.50^{\mathrm{a}}$ & $4.22^{\mathrm{d}}$ & $5.00^{\mathrm{bc}}$ & $4.58^{\mathrm{cd}}$ \\
\hline
\end{tabular}

Means followed by the same letter in the column are not significantly different at $1 \%$. DPE: number of days to plant emergence, Ouaga: Oua gado ugo u, Bobo: Bo bo Dioulasso.

Table 7 Squared Cosines of 11 Characters on tree Factors and total variability explained of 11.

\begin{tabular}{|lccc|}
\hline Variables & \multicolumn{2}{c|}{ Principal components } & F3 \\
\hline Plant height $(\mathrm{cm})$ & F1 & F2 & 0.021 \\
\hline Stem diameter $(\mathrm{cm})$ & 0.882 & 0.015 & 0.008 \\
\hline Primary branches number & 0.839 & 0.004 & 0.045 \\
\hline Petiole length $(\mathrm{cm})$ & 0.519 & 0.282 & 0.010 \\
\hline Leaflet length $(\mathrm{cm})$ & 0.896 & 0.001 & 0.012 \\
\hline Leaflet width $(\mathrm{cm})$ & 0.934 & 0.002 & 0.005 \\
\hline Fruit width $(\mathrm{cm})$ & 0.882 & 0.004 & 0.018 \\
\hline Fruit length $(\mathrm{cm})$ & 0.376 & 0.274 & 0.058 \\
\hline 50\%flowering & 0.266 & 0.589 & 0.068 \\
\hline Leaves biomass $(\mathrm{g})$ & 0.633 & 0.223 & 0.599 \\
\hline DPE & 0.080 & 0.229 & 0.063 \\
\hline Eigenvalue & 0.197 & 0.361 & 0.905 \\
\hline Variability $(\%)$ & 6.505 & 1.983 & 8.229 \\
\hline Cumulative $(\%)$ & 59.132 & 18.029 & 85.391 \\
\hline
\end{tabular}

Values in bold correspond for each character to the factor for which the squared cosine is the largest and show the association of characters with the principal component, DPE: number of days to plant emergence

Cluster 3 on the contrary, contains mostly the accessions from the other cities and recently introduced in cultivation. This cluster has the weakest agronomic performances.

\section{Discussions}

4.1 Agromorphological variability and farmer's nomenclatures of local varieties

The study revealed a diversity of local names of $C$. gynandra derived primarily from morphological characteristics.
These results are in accordance with Jiro et al. (2011) those have studied on okra and revealed that farmers name their ecotypes using agromorphological and phenotypic characteristics such as stem and fruits color, fruit shape, vegetative cycle (long or short) and those of $\mathrm{N}$ 'da et al. (2013) studied on maize has permitted to know that farmers identify varieties on the basis of their grain colors. Thus, green morphotype with great plant height, long cycle, few flowers and high leaves biomass observed corresponds to the one called by producers "keneb Pelga" (white C. gynandra) or "Tampouy kenebdo" (C. gynandra L. of Tampouy)" or "Baskuy kenebdo" (C. gynandra of Baskuy). 


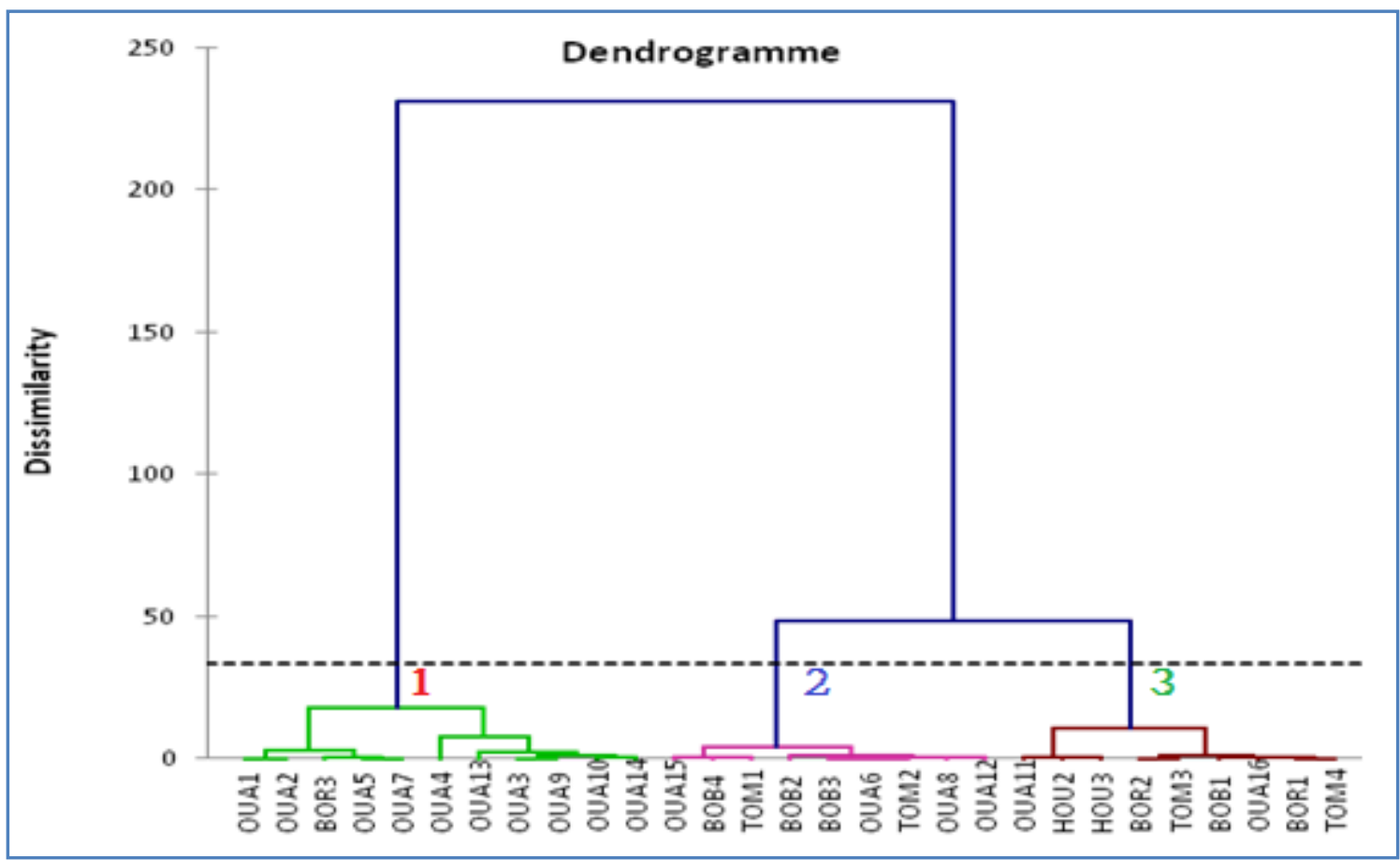

Figure 4 Dendrogram of Dissimilarity among 30 accessions of Cleome gynandra L. using Ward's Minimum Variance Method of Cluster Analysis.

Violet morphotype corresponds to the name "keneb miougou" (Red C. gynandra). The designation "keneb raaga" (Male $C$. gynandra) by some producers would correspond to the small violet morphotype with a small plant height, feeble leaves biomass, abun dant flowers and short cycle.

\subsection{Producers preferential characters}

In gardens, the selection of producers is oriented to the characters such as great plant height, green stem, cleared-green leaf, long cycle, high leaves biomass, high primary branches number and small flowers number. These characters match to those identified by the survey as preferential characters of most producers. The selection leads to the suppression of some wild characters and favors those desired. This selection pressure would explain the phenotypic differences and the significant differences of reproductive and growth vegetative parameters observed between the accessions from the three seeds obtainment modes on one hand and between the accessions from Ouagado ugo u and those from the other cities on the other hand.

The domestication that automatically provokes a gradual evolution of populations by spreading them from the wild plants which they derive from (Bouharmont, 1995) also explains the differences between the accessions of different seeds obtainment modes. Indeed, the accessions from selection benefited a longer time of domestication than those recently collected from the wild ecotypes which have undergone few cultivation cycles. According to Bouharmont (1995), domesticated the plants are characterized by hypertrophy of harvested organs (stems, leaves, fruits, etc.), their high yield, their uniformity, their taste or their color. The best performances of the accessions from Ouaga dougou compared to those from the other localities could be explained by the fact that the domestication and the selection are more advanced in Oua gado ugo $u$ than in those other cities where the cultivation of the plant for the selling comes first. Similar results (K'Opondo, 2011; Masuka et al., 2012) have revealed that the differences observed between agronomic characters of Kenyan morphotypes and those of Zimbabwe could be due to a greater selection in Kenya where the domestication is more advanced compared to Zimbabwe where it is still only confined to only research centers. Contrary to the observations of some producers, great pubescence of plants could not be related to green morphotype.

\subsection{Diversity organization}

The accessions were grouped according to their geographical origin and the degree of selection pressure practiced by the producers. The accessions of the capital, Ouagadougou, mostly from selection, were met almost in the same cluster (cluster 1). The cluster contains accessions of better agronomic performances. The demand of C. gynandra is higher in urban centers than in rural zones as also noted by Bosire (2014) in Kenya. Thus, the producers of Ouaga dougou the capital city, to respond to this important consumers demand, produce $C$. 
gynandra several times per year (several cultivation cycles in a year) on one hand, and practice a selection oriented to the consumers preferential characteristics one the other hand. The cluster 2, made up of diverse geographical origin accessions, contains accessions obtained by purchase / donation. This cluster is more heterogeneous than the others. Indeed, the seeds obtainment mode per purchase/donation favors genetic material exchanges bet ween different localities. This explains the fact that some accessions grown in Ouagadougou gardens, but initially originated from elsewhere (Kongoussi for example), are regrouped with the accessions of other localities. Cluster 3, made up of diverse geographical origins accessions, contains those of feeble agronomic performances; recently introduced in cultivation and including always several wild characters. This is the cluster of accessions which have undergone lo wer selection pressure.

\section{Conclusions}

The study revealed the relationship between farmer's nomenclatures of local varieties and the agromorphological characteristics of accessions of Cleome gynandra L. in Burkina Faso. The selection for cultivation of the plant based on the phenotypic interests of the farmers which can further be used for varietal improvement such as the green color of the stem, the cleared-green color of leaves, the low production of flowers, the late cycle of the plant, the long height of plant, the large dimensions of leaves, the high leaves biomass and the high primary branches number.

All these characters, highly heritable, discriminate the accessions studied. The study also revealed that the degree of selection varies according to the city of collection and could be primarily responsible for the structuring of the agromorphological diversity. Gardeners whose produce Cleome gynandra L. for marketing exercise a stronger selection pressure than those whose produce it for family consummation.

\section{Conflict of inte rest}

Authors give Journal of Experimental Biology and Agricultural Sciences the right to re-use commercially or non-commercially of this article, as long as the original author and source are properly at tributed.

\section{Acknowledgements}

This research has been supported by International Foundation for Science (IFS), Sweden, through a scholarship given to Zakaria KIEBRE.

\section{References}

Agbo AE, Kouamé C, Anin AOL, Soro LC, N'zi J-C, Fondio L, Gnakri D (2014) Seasonal variation in nutritional compositions of spider plant (Cleome gynandra L.) in south
Côte d'Ivoire. International Journal of Agricultural Policy and Research 2: 406-413. http://dx.doi.org/10.15739/IJAPR.013.

Bosire KO (2014) Effects of Chinsaga (Gynandropsis gynandra) on Haematological Profile and Markers of Iron Metabolism in Kenyan Breastfeeding Women. Ph D thesis submitted to the University of Nairobi.

Bouharmont J (1995) Création variétale et amélioration des plantes. Agronomie moderne. Bases physiologiques et agronomiques de l'amélioration de la production végétale, Hatier. Paris, 313-337.

Chweya JA, Mnzava NA (1997) Cat's whiskers Cleome gynandra $L$. promoting the conservation and use of underutilized and neglected crops 11. Institute of Plant Genetics and Crop Plant Research, Gatersleben/International Plant Genetic Resources Institute, Rome, Italy, Pp54.

Department of Agriculture Forestry and Fisheries (DAFF) (2010) Cleome. Resource Centre, Pretoria, South Africa.

Jiro H, Sawadogo M, Millogo J (2011) Caractérisations agromorphologique et anatomique du gombo du Yatenga et leur lien avec la nomenclature locale des variétés. Sciences \& Nature 8: $23-36$.

Johnson HW, Robinson HF, Comstock RE (1955) Estimates of Genetic and Environmental Variability in Soybeans. Agronomy Journal 47:314-318.

K'Opondo FBO (2011) Morphological characterization of selected spiderplant (Cleome gynandra L.) types from western Kenya. Annals of Biological Research 2: 54- 64.

Masuka A, Goss M, Mazarura U (2012) Morphological Characterization of Four Selected Spider Plant (Cleome Gynandra L.) Morphs from Zimbabwe and Kenya. Asian Journal of Agriculture and Rural Development 2: 646 - 657.

Millogo-Rasolodimby J (2001) L'Homme, le climat et les ressources alimentaires végétales en périodes de crise de subsistance au cours du $20^{\text {ème }}$ siècle au Burkina Faso. These de doctorat soumise à l'Université de Ouaga dougou.

N'Da HA, Akanvou L, Kouakou CK (2013) Gestion locale de la diversité variétale du maïs (Zea mays L.) violet par les Tagouana au Centre-Nord de la Côte d'Ivoire. International Journal of Biological and Chemical Sciences 7: 2058-2068

Short PS (2011) Capparaceae. In Short PS and Cowie ID (Eds), Flora of the Darwin Region. Northern Territory Herbarium, Department of Natural Resources, Environment, the Arts and Sport 1: 1-24.

Soro CL, Ocho-Anin AtchibrI AL, Armand KKK et Christophe K (2012) Evaluation de la composition 
297

nutritionnelle des légumes feuilles. Journal of Applied

Biosciences 51: 3567-3573.
Thiombiano A, Kampmann D (2010) Atlas de la biodiversité de l'Afrique de l'Ouest, Tome II : Burkina Faso, Oua gado ugo u et Frankfurt/Main. 